\title{
The Insect Microcosm of Western Juniper Berries
}

\author{
By Lindsay A. Dimitri, Kirk C. Tonkel, William S. Longland, and Brian G. Rector
}

\section{On the Ground}

- Expansion of western juniper has been a major concern of ranchers and managers working on rangelands.

- Insects and mites associated with juniper berries can impact juniper seed production, but little is known about arthropods inhabiting western juniper or their effects on seeds.

- Our study of insects and other arthropods found inside juniper berries at two sites in northeastern California found 37 species of insects and one mite species, ranging from those that eat berries or seeds to parasitoid insects that develop from eggs laid inside other insects, ultimately killing their host, and hyperparasitoids that parasitize other parasitoids.

- We identified several granivores that consume western juniper seeds and, when abundant, may reduce the production of viable seeds considerably.

Keywords: arthropods, granivores, insects, juniper berries, juniper expansion, mites, parasitoids, seeds, western juniper.

Rangelands 36(3):8-11

doi: 10.2111/Rangelands-D-13-00070.1

(C) 2014 The Society for Range Management

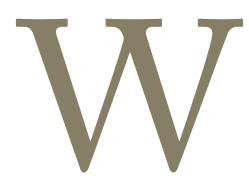

estern juniper (Juniperus occidentalis) is a native conifer found in eastern Oregon, northeastern California, western Idaho, southeastern Washington, and in small patches in northwestern Nevada. It has been expanding its range and increasing in density for over a century due to factors such as fire suppression, grazing, and climate change. ${ }^{1}$ Although this species has expanded and contracted its range during past climate fluctuations, the current expansion appears to be occurring more rapidly. Some of the issues associated with juniper expansion include the replacement and fragmentation of important sagebrush steppe habitat, canopy closure reducing availability of herbaceous understory plants to livestock and wildlife, and intense wildfires that result in conversion to invasive annual grasslands. Extensive efforts have been made to remove western juniper and restore the shrublands being replaced. Management practices such as prescribed burning, mechanical removal (chaining, felling with chainsaws) and herbicides are used to thin or eliminate juniper in a given area. Despite the extensive literature detailing western juniper expansion, there are many aspects of its ecology that remain understudied, including interactions with seed predators and seed dispersers that are potentially important aspects of the ongoing expansion. Like other juniper species, western juniper does not reproduce vegetatively (for example, by root sprouting), so this expansion is exclusively attributable to the establishment of new seedlings. Therefore, documenting the seed and seedling ecology of western juniper is essential to understanding the rapid expansion of this species.

Juniper seeds are produced within female cones, often called "berries." Juniper berries are a textbook example of evolutionary convergence because of their similar appearance and function relative to true berries and fruits. Specifically, like a true berry, juniper berries attract fruit-eating birds which function as seed dispersers by defecating seeds of consumed berries after the surrounding fruit pulp is digested.

We first set out to study seed production by western juniper trees in order to estimate seed availability for dispersal by animals within a given area. After noticing the substantial amount of insect-damaged berries on some trees, we decided to further investigate associated arthropod communities. Some previous research has shown that insects and mites (which are not insects, but are arthropods) can significantly reduce juniper seed yield. For example, Keen ${ }^{2}$ reported that a seed-feeding wasp in the genus Eurytoma had destroyed 25\% of western juniper seeds at some sites, and mites inhabiting juniper seeds have been found to destroy the majority of seeds on a single tree. ${ }^{3}$ Our research goal was simply to identify seed-feeding insects that impact the seed crop by reducing the number of seeds available for dispersal and seedling recruitment, but we have discovered a diverse array of arthropods too interesting to ignore. 
Since Marcovitch ${ }^{4}$ described the insect community of eastern juniper (J. virginiana) berries almost 100 years ago, there have not been any further comprehensive descriptions of arthropods inhabiting cones of any North American juniper species and there have not been any publications describing the insect community of western juniper in particular. With active management of western juniper occurring throughout its range, it is important to understand the biodiversity associated with these trees as well as factors affecting seed production and seedling establishment. Because granivorous (i.e., seed-eating) insects can greatly reduce the seed yield in any given plant species, knowledge of the insects that feed upon western juniper seeds and the proportion of seeds eaten could provide insight into the number of viable seeds available for dispersal. From 2009 to present, we have been collecting juniper berries for dissection and rearing of associated insects at two field sites in northeastern California twice a year, once in the spring and once in the fall.

\section{Field Studies in Northeastern California}

Our investigations took place at two field sites in northeastern California: Madeline and Shinn Peak. These collection sites are located in the southern portion of western juniper's known distribution. We sampled 20 trees in the fall and 10 trees in the spring at both sites. For each collection, we typically collected several hundred berries from each tree sampled, placed them in a sealed plastic bag, and returned them to the lab to be stored temporarily in a freezer. We randomly selected 100 berries from each bag for dissection and placed remaining berries in a petri dish to rear adult insects from any larvae inside the berries. Berries were also collected from trees adjacent to study plots and placed in light boxes to rear additional adults.

Each of the 100 berries per tree was measured, weighed, and carefully dissected. When immature insects (larvae or pupae) or adults were found, we recorded location (fruit or seed), condition, color, and a brief description. Presence and condition of shed exoskeletons, eggs, and other potentially relevant details were also recorded.

Our collections yielded over 30 different species of arthropods. Relationships between some inhabitants are uncertain, but are quite diverse, since we know that they include frugivorous and granivorous species (cone- and seed-feeders, respectively; Fig. 1), predators of other insects, parasitoids (insects that develop from eggs laid inside other insects, ultimately killing their host; Fig. 2), hyperparasitoids (parasitoids of other parasitoids), and inquilines (species that harmlessly cohabitate with other species). Of particular interest to this study are the seed-destroying arthropods collected, which include species of several insect orders, such as beetles (Coleoptera), moths (Lepidoptera), wasps (Hymenoptera), and flies (Diptera), as well as a family of mites (Eriophyidae).

So far 37 species of insects and one mite species have been reared or dissected from western juniper berries collected at our sites. Particular habits of numerous collected species are

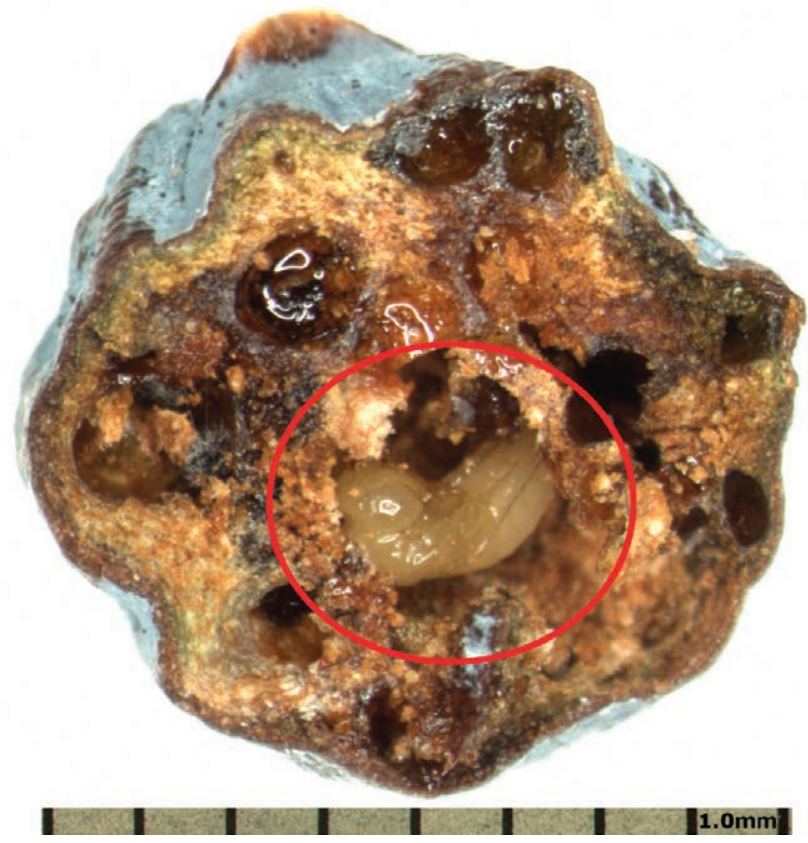

Figure 1. Wasp pupa (in red circle) occupying dissected western juniper berry (possible parasitoid of a granivore).

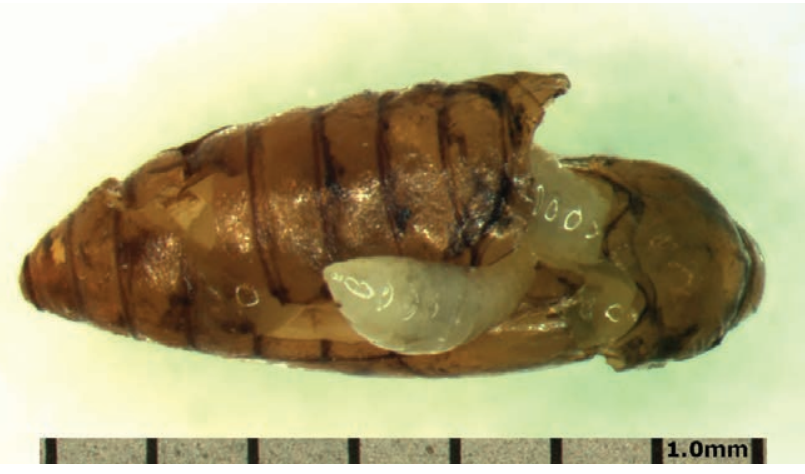

Figure 2. Moth pupa removed from dissected western juniper berry with parasitoid wasp larvae emerging from host (parasitized granivore).

not yet known and some of the species may be new to science. Adults of at least seven species of phytophagous arthropods have been found, including a weevil, Anthonomus sanborni (Coleoptera: Curculionidae); a fruit fly, Paraterellia varipennis (Diptera: Tephritidae); a tiny seed-feeding wasp, Eurytoma sp. nr. juniperina (Hymenoptera: Eurytomidae); three small moths, Periploca juniperi and Periploca serrulata (Lepidoptera: Cosmopterigidae), and Henricus infernalis (Lepidoptera: Tortricidae); and a plant mite, Trisetacus quadricetus (Acari: Eriophyidae). These arthropods feed inside the berry, usually in the larval form (e.g., caterpillar), before metamorphosing into adults either within or outside of the berry. The adults search for mates and eventually lay eggs in other berries.

Some of these species were very common and others relatively rare among our samples. Of the 37 species of berry-inhabiting insects encountered at our sites, 19 are rep- 


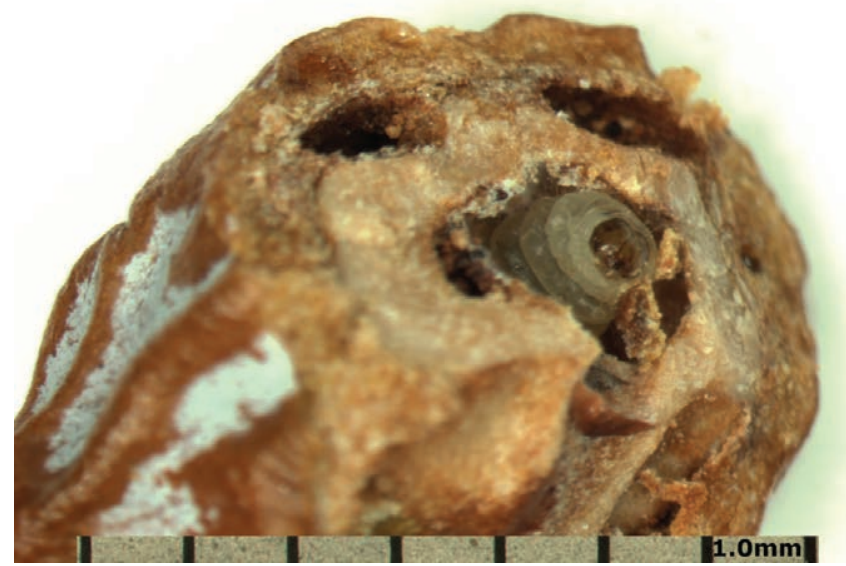

Figure 3. Moth caterpillar inside the seed of a dissected western juniper berry (example of a granivore).

resented by five or fewer adults out of the $420+$ reared or dissected insects identified from berries. Nearly half of the $420+$ adults belong to three groups-Periploca spp., Eurytoma sp. nr. juniperina, and a parasitic wasp species in the family Pteromalidae.

Periploca spp. are frequently reared and dissected out of our sample berries. This genus contains several species known to attack a number of different juniper species. ${ }^{5}$ Eurytoma sp. nr. juniperina also attacks berries, destroying $25 \%$ of the seeds on a tree in some cases. ${ }^{2}$ Unlike the feeding habits of E. juniperina reported in Marcovitch, ${ }^{4}$ this wasp consumes the seed during development but does not consume the fleshy portion of the berry. The other frequently encountered adult insect we collected is a pteromalid wasp, likely parasitizing berry inhabitants, since members of this large family are known to generally parasitize larvae and/or pupae of small phytophagous insects. ${ }^{6}$ Densities of arthropods feeding on the seeds or husk (i.e., the fleshy part of the berry) varied greatly from tree to tree. An impressive diversity of parasitoids and hyperparasitoids are associated with both seed and husk feeders, potentially regulating populations of these insects. The most common immature insect species dissected from berries was a moth caterpillar that consumes the seed as well as some of the fruit or husk (Fig. 3).

We have created a food web to illustrate known and potential relationships among the insects discovered so far (Fig. 4). Further studies will help to connect more of the dots in this very complex arthropod community sustained within this unique resource.

In summary, western juniper harbors a diverse and complex community of arthropods in its berries. Some of these species can drastically reduce a tree's seed yield within a given year, leaving almost no seeds available for dispersal, while

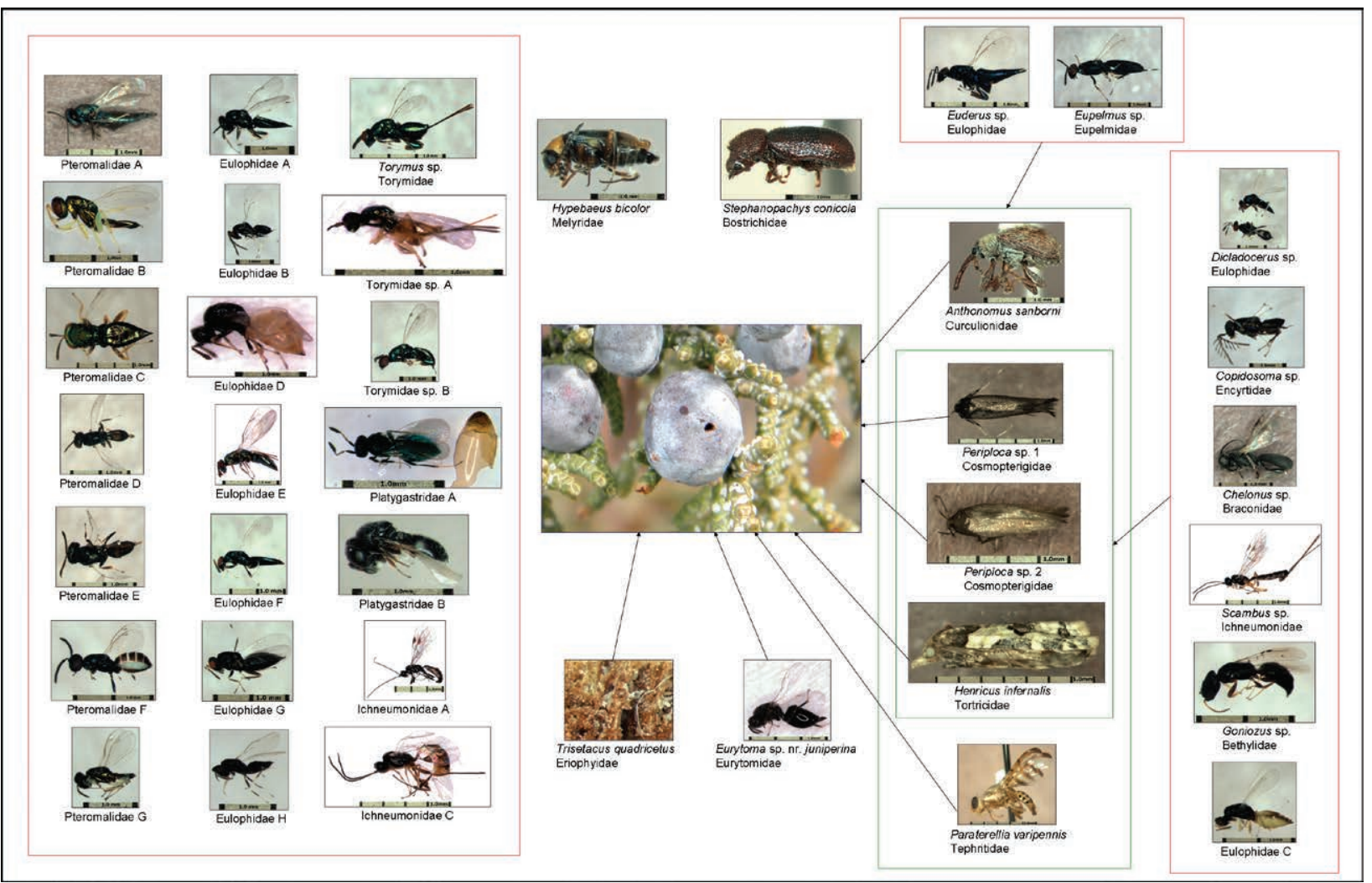

Figure 4. Food web illustrating the 38 species of arthropods reared or dissected as adults from western juniper berries. The relationships of the 21 species of Hymenoptera boxed on the left are not yet known. Other arthropods pictured were found feeding internally on berries or parasitizing those phytophages. 
others seem to only consume the husk. However, insects that feed on the husks can still decrease the number of seeds available for dispersal. Garcia et al. ${ }^{7}$ found that birds avoided or rejected berries infested with or damaged by insects. Therefore husk-feeding insects disrupt the dispersal of juniper seeds by birds, and seeds do not continue to develop if the husk is fed upon before the berry matures.

The expansion and control of western juniper can be a controversial topic, but this should not deter researchers from continuing to study the ecology of this resilient conifer. As efforts to control juniper throughout the west continue, it is important to have a complete picture of the reproduction and biodiversity associated with this expanding tree and use this information to aid management efforts.

\section{Future Directions}

Future research efforts will employ DNA "fingerprinting" to match unidentified immature insects dissected from berries to identified adult species. It is often not possible to make species-level identifications of immature insects, so the use of DNA fingerprinting should reveal the identity of many larvae and pupae (i.e., cocoons) that we collected. Since immature insects were encountered much more frequently than adults in our dissections, identifying these individuals will allow us to better quantify and understand the role of each of these characters in this juniper berry microcosm and especially to determine which species have the greatest impacts on seed production of western juniper.

\section{Acknowledgments}

Thanks to Josh Holman for help in collecting berries and Carly Mathat for assistance with figures. Dr John W. Brown, SEL/CTSU, identified Henricus infernalis (Lepidoptera: Tortricidae), Dr Matthew Buffington, SEL/CTSU, identified Goniozus sp. (Hymenoptera: Bethylidae), Dr Robert Carlson, SEL/CTSU (retired), provided guidance for Ichneumonidae identifications, Dr Michael Ivie, Montana State University, identified Stephanopachys conicola (Coleoptera:
Bostrichidae), Dr Sangmi Lee, Mississippi State University, identified Periploca spp. (Lepidoptera: Cosmopterigidae), and Dr Jens Prena, SEL/CTSU, identified Anthonomus sanborni (Coleoptera: Curculionidae). This paper is a contribution of the USDA, ARS, Great Basin Rangelands Research Unit, Reno, Nevada.

\section{References}

1. Miller, R. F., And J. A. Rose. 1999. Fire history and western juniper encroachment in sagebrush steppe. Journal of Range Management 52:550-559.

2. Keen, F. P. 1958. Cone and seed insects of western forest trees. Washington, DC, USA: USDA. Technical Bulletin 1169. 2 p.

3. Morgan, C. V. G., And A. F. Heduin. 1960. Notes on the juniper berry mite, Trisetacus quadrisetus (Thomas) (Acarina: Eriophyidae), in British Columbia. Canadian Entomologist 92:608610.

4. Marcovitch, S. 1915. The biology of juniper berry insects, with descriptions of new species. Annals of the Entomological Society of America 8:163-181.

5. Hodges, R. W. 1978. The moths of America north of Mexico. Fascicle 6.1 Gelechioidea Cosmopterigidae. London, UK: E. W. Classey Limited and the Wedge Entomological Research Foundation. 12 p.

6. Gibson, G. A. P., J. T. Huber, and J. B. Woolley [eds.] 1997. Annotated keys to the genera of nearctic Chalcidoidea (Hymenoptera). Ottawa, ON, Canada: NRC Research Press. 794 p.

7. García, D., R. Zamora, J. M. Gómez, and J. A. Hódar. 1999. Bird rejection of unhealthy fruits reinforces the mutualism between juniper and its avian dispersers. Oikos 85:536-544.

Authors are Research Associate and Graduate Student, University of Nevada, Reno, NV 89557, USA, Lindsay.Dimitri@ars. usda.gov (Dimitri); and Biological Science Technician (Tonkel), Research Ecologist (Longland), and Research Entomologist (Rector), USDA, ARS, Great Basin Rangelands Research, Reno, NV 89512, USA. 